\title{
PENGOLAHAN PRODUK IKAN DAN PEMBERDAYAAN KELOMPOK MASYARAKAT
}

\author{
Sisca Elviana ${ }^{1 *}$, Sunarni ${ }^{1}$, Nurhening Y Ekowati ${ }^{2}$, Heny V Saiya ${ }^{3}$ \\ ${ }^{1} J u r u s a n$ Manajemen Sumber Daya Perairan, Fakultas Pertanian, Universitas Musamus \\ 2 Jurusan Manajemen Agroteknologi Fakultas Pertanian, Universitas Musamus \\ ${ }^{3}$ Jurusan Manajemen Peternakan, Fakultas Pertanian, Universitas Musamus \\ Korespondensi: siscaelviana@unmus.ac.id
}

\begin{abstract}
ABSTRAK
Kegiatan pengabdian ini bertujuan memberdayakan masyarakat Kelurahan Kamundu khususnya mereka yang kesehariannya sebagai ibu rumah tangga, untuk dapat mengolah ikan kakap menjadi beberapa produk makanan, sehingga memenuhi kebutuhan protein hewani khususnya bagi anak - anak. Ikan dapat dioleh menjadi beraneka ragam menu makanan baik sebagai lauk maupun sebagai camilan antara lain, bakso, nugget, sosis, kerupuk, abon, dendeng, perkedel dan lain sebagainya. Target yang ingin dicapai dalam kegiatan pengabdian ini berupa adanya tambahan pengetahuan dan keterampilan bagi masyarakat kelurahan Kamundu dalam mengolah ikan khususnya ikan kakap menjadi berbagai jenis makanan. Metode yang dilakukan dalam kegiatan pengabdian ini berupa motivasi dan sosialisasi kepada masyarakat, kemudian dilanjutkan dengan pelatihan dalam pengolahan ikan kakap menjadi aneka produk makanan berupa bakso, sosis dan perkedel. Hasil dari kegiatan pengabdian ini adalah masyarakat cukup antusias dalam mengikuti seluruh kegiatan ditunjukkan dengan peran serta peserta mengikuti dan mempraktektan seluruh pembuatan produk.
\end{abstract}

Katakunci : Ikan Kakap, Pengolahan, Masyarakat

\section{PENDAHULUAN}

Kandungan gizi yang tinggi dibutuhkan khususnya bagi anak-anak untuk tumbuh dan berkembang khususnya pada usia pra sekolah dan sekolah dasar. Dalam pertumbuhan dan perkembangan anak memerlukan zat gizi agar proses pertumbuhan dan perkembangan berjalan dengan baik apabila gizi seimbang yang dikonsumsi tidak terpenuhi, pencapaian pertumbuhan dan perkembangan anak terutama perkembangan motorik yang baik akan terhambat (Gunawan dkk, 2011).

Potensi akan produksi ikan di Kabupaten Merauke dapat memenuhi kebutuhan gizi khususnya bagi anak-anak, namun anak - anak usia pra sekolah dan sekolah dasar pada umumnya cenderung memilih - milih makanan dan terkadang cepat bosan dengan penyajian yang monoton terlebih untuk bahan makanan seperti ikan. Dengan menu yang monoton hanya sebatas di goring, di kuah ataupun dibakar, menyebabkan minat akan olahan ikan ini menjadi terbatas, hal ini menyebabkan penyerapan gizi yang maksimal tidak dapat di peroleh, sehingga untuk mengatasi olahan yang monoton dapat dilakukan dengan diversifikasi berbahan dasar daging ikan, cukup banyak olahan makanan berbahan dasar ikan yang dapat disajikan dan digemari anak - anak, seperti bakso, nugget, sosis, perkedel, cilok, dan lain sebagainya.

Olahan makanan berbahan dasar ikan, sangat besar manfaatnya untuk meningkatkan kesukaan khususnya anak - anak, namun hal ini perlu juga didukung oleh keterampilan orang tua dalam melakukan pengolahan sehingga diperoleh makanan yang higienis, sehat, bergizi dan beragam. Di Kelurahan Kamundu, cukup banyak masyarakat yang berprofesi sebagai ibu rumah tangga, namun belum banyak 
yang memiliki keterampilan dalam mengolah ikan, hal ini menyebabkan konsumsi akan ikan yang diminati anak - anak pra sekolah dan sekolah dasar menjadi terbatas.

\section{METODE PELAKSANAAN KEGIATAN}

1. Waktu dan Tempat Pelaksanaan

Pengabdian dilaksanakan pada hari kamis, 14 Maret 2019. Pelaksanaan pengabdian di RT 06/RW 02 Kelurahan Kamundu Distrik Merauke dengan tema" Pengolahan Produk Ikan/Daging serta Pemberdayaan Kelompok Masyarakat". Saat ini di RT 06/RW 02 ini dipimpin oleh Bapak Yoseph Timun.

\section{Prosedur kegiatan}

Kegiatan pengabdian kepada masyarakat dengan judul "Pengolahan Produk Ikan Dan Pemberdayaan Kelompok Masyarakat" ini melalui 2 tahap, tahap pertama berupa survey dan sosialisasi dan tahap kedua berupa pelatihan pembuatan bakso, sosis dan perkedel.

a. Pembuatan Bakso

Bahan yang digunakan dalam pembuatan bakso ikan berupa Filet ikan $500 \mathrm{gr}$, Tepung tapioca $100 \mathrm{gr}$, Bawang putih 5 siung, Lada halus $5 \mathrm{gr}$, Garam $20 \mathrm{gr}$, Daun jeruk 2 lembar, Putih telur 1 butir, Penyedap secukupnya, Es batu, Air untuk merebus.

Metode dalam pembuatan bakso ikan yaitu menghaluskan filet ikan bersama daun jeruk, mencampur secara merata filet ikan yang telah dihaluskan dengan bumbu (bawang putih, garam, lada halus, penyedap), menambahkan putih telur dan tepung pada adonan ikan dicampur bersamaan dengan es batu, hingga adonan kalis dan mudah dibentuk bulat kemudian memasukkan bulatan adonan ikan yang telah dibentuk pada air, dan direbus hingga matang.

Bahan yang digunakan dalam pembuatan sosis yaitu Filet ikan $500 \mathrm{gr}$, Tepung tapioca $50 \mathrm{gr}$, Bawang putih 5 siung, Lada halus $10 \mathrm{gr}$, Garam $20 \mathrm{gr}$, Telur 1 butir, Pala / jahe secukupnya, Penyedap secukupnya, Selongsong (pencetak sosis).

b. Pembuatan Sosis

Proses pembuatan sosis dimulai dari menghaluskan filet ikan hingga benarbenar halus, mencampurkan filet ikan yang telah halus dengan telur dan bumbu yang telah dihaluskan sebelumnya (bawang putih, lada, garam, pala, penyedap), memasukkan adonan ke dalam selongsong (selongsong dapat menggunakan plastic es), padatkan adonan sosis didalam selongsong untuk mendapatkan hasil yang bagus dan terakhir mengkukus sosis yang telah dibentuk selama kurang lebih 15 menit.

c. Pembuatan Perkedel

Bahan yang digunakan dalam pembuatan perkedel berupa Filet ikan $500 \mathrm{gr}$, Bawang putih 5 siung, Lada halus $5 \mathrm{gr}$, Ketumbar $5 \mathrm{gr}$, Garam $20 \mathrm{gr}$, Telur 1 butir, Tepung terigu $100 \mathrm{gr}$, Penyedap secukupnya dan Sayuran sebagai pelengkap (wortel, kol dsb).

Proses pembuatan perkedel yaitu diawali dengan menghaluskan filet ikan, mencampur secara merata filet ikan yang telah dihaluskan dengan bumbu yang telah dihalukan (bawang putih, garam, lada halus, ketumbar, penyedap), menambahkan 
telur dan tepung pada adonan hingga tercampur rata dan terakhir mengoreng adonan hingga matang dan sajikan, dapat digunakan sebagai lauk atau cemilan sehat bagi si kecil.

\section{HASIL DAN PEMBAHASAN}

Kegiatan pengabdian mandiri diawali dengan pembagian brosur produk olahan ikan dan dilanjutkan dengan kegiatan pelatihan pembuatan hasil olah ikan. Ikan dapat dioleh menjadi beraneka ragam menu makanan baik sebagai lauk maupun sebagai camilan antara lain, bakso, nugget, sosis, kerupuk, abon, dendeng, perkedel dan lain sebagainya. Pada kegiatan ini diperkenalkan produk hasil olahan ikan berupa bakso, sosis dan perkedel.

Pelatihan yang pertama dilakukan adalah pembuatan bakso ikan. Bakso adalah jenis bola daging yang lazim ditemukan pada masakan Indonesia, bakso pada umunya terbuat dari daging, namun dapat juga terbuat dari ikan ataupun udang.

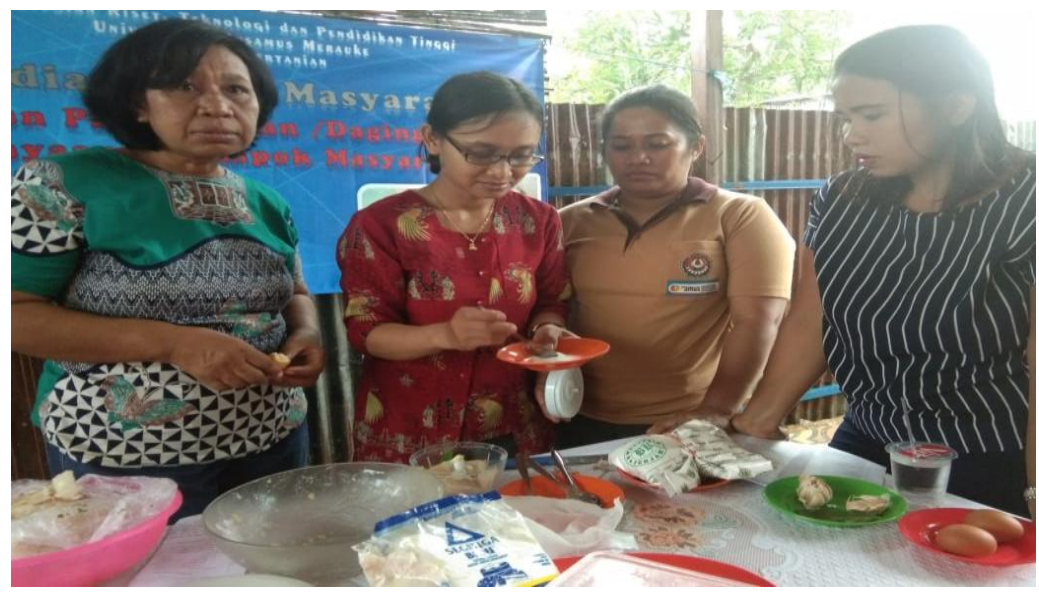

Gambar 1. Pelatihan Pembuatan Bakso Ikan Oleh Masyarakat

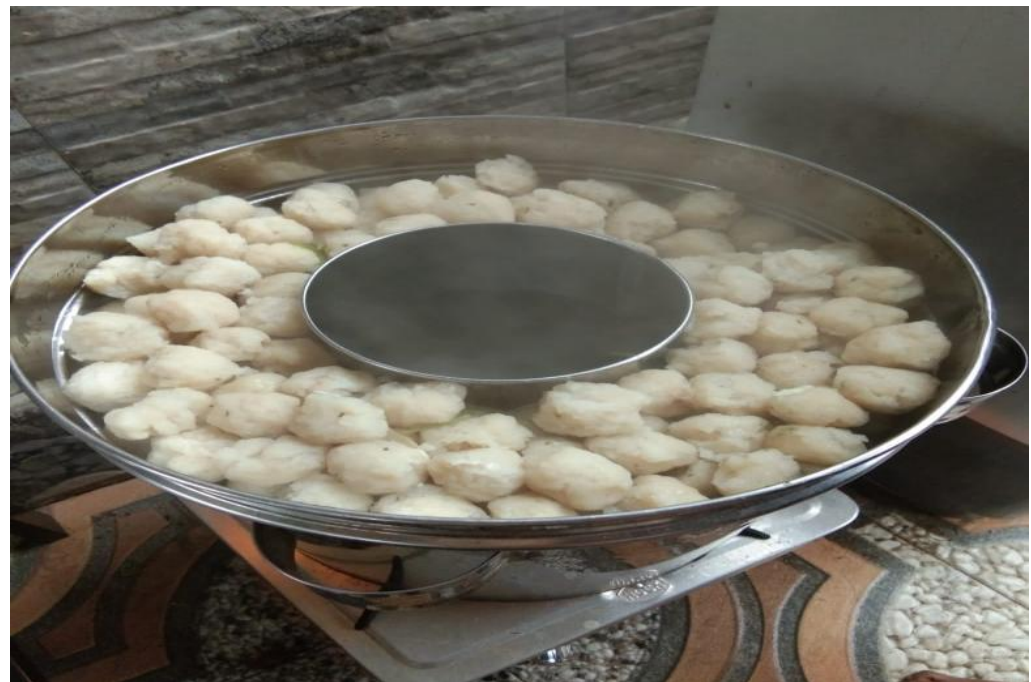

Gambar 2. Bakso Hasil Pelatihan Oleh Tim Pelatihan 
Kegiatan pelatihan pertama adalah pembuatan bakso ikan yang dimulai dengan menghaluskan filet ikan bersama daun jeruk, mencampur secara merata filet ikan yang telah dihaluskan dengan bumbu (bawang putih, garam, lada halus, penyedap), menambahkan putih telur dan tepung pada adonan ikan dicampur bersamaan dengan es batu, hingga adonan kalis dan mudah dibentuk bulat kemudian memasukkan bulatan adonan ikan yang telah dibentuk pada air, dan direbus hingga matang.

Kegiatan pelatihan kedua adalah pembuatan sosis ikan. Proses pembuatan sosis dimulai dari menghaluskan filet ikan hingga benar-benar halus, mencampurkan filet ikan yang telah halus dengan telur dan bumbu yang telah dihaluskan sebelumnya (bawang putih, lada, garam, pala, penyedap), memasukkan adonan ke dalam selongsong (selongsong dapat menggunakan plastic es), padatkan adonan sosis didalam selongsong untuk mendapatkan hasil yang bagus dan terakhir mengkukus sosis yang telah dibentuk selama kurang lebih 15 menit.

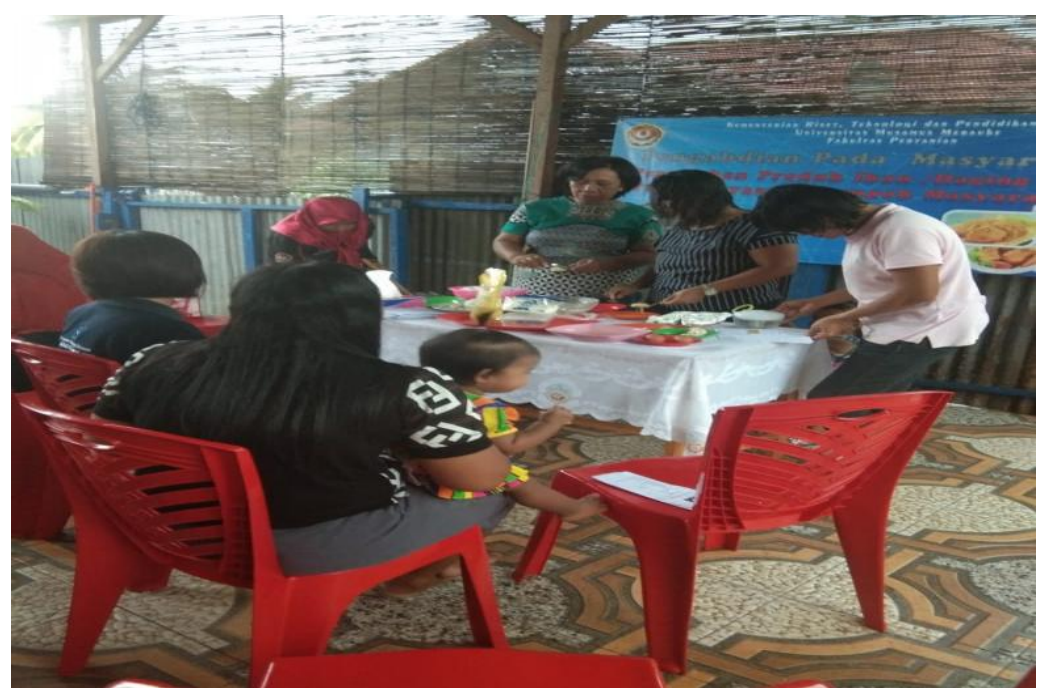

Gambar 3. Pelatihan Pembuatan Sosis Ikan Oleh Masyarakat

Sosis ikan adalah salah satu olahan yang dibuat dari pasta ikan yang dicampur dengan bumbu kemudian dibungkus atau dikemas dengan usus atau pengemas lainnya yang disebut selongsong / casing. Sosis ikan dapat menjadi salah satu pilihan menu makanan yang lezat dan bergizi dalam pilihan konsumsi ikan.

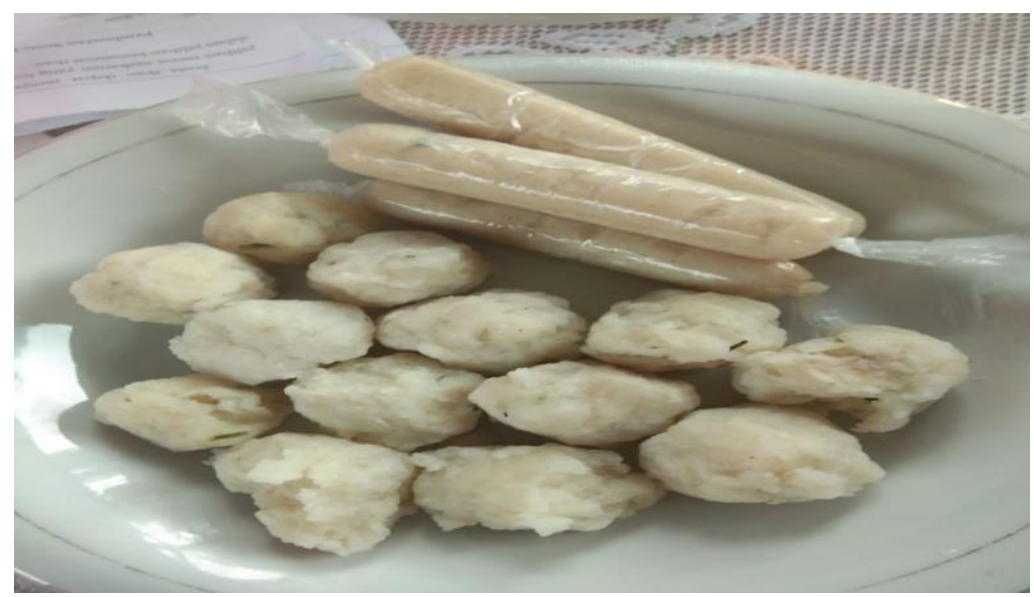

Gambar 4. Hasil Pelatihan Sosis Ikan 
Kegiatan ketiga adalah pelatihan pembuatan perkedel ikan. Pelatihan diawali dengan diawali dengan menghaluskan filet ikan, mencampur secara merata filet ikan yang telah dihaluskan dengan bumbu yang telah dihalukan (bawang putih, garam, lada halus, ketumbar, penyedap), menambahkan telur dan tepung pada adonan hingga tercampur rata dan terakhir mengoreng adonan hingga berwarna coklat.

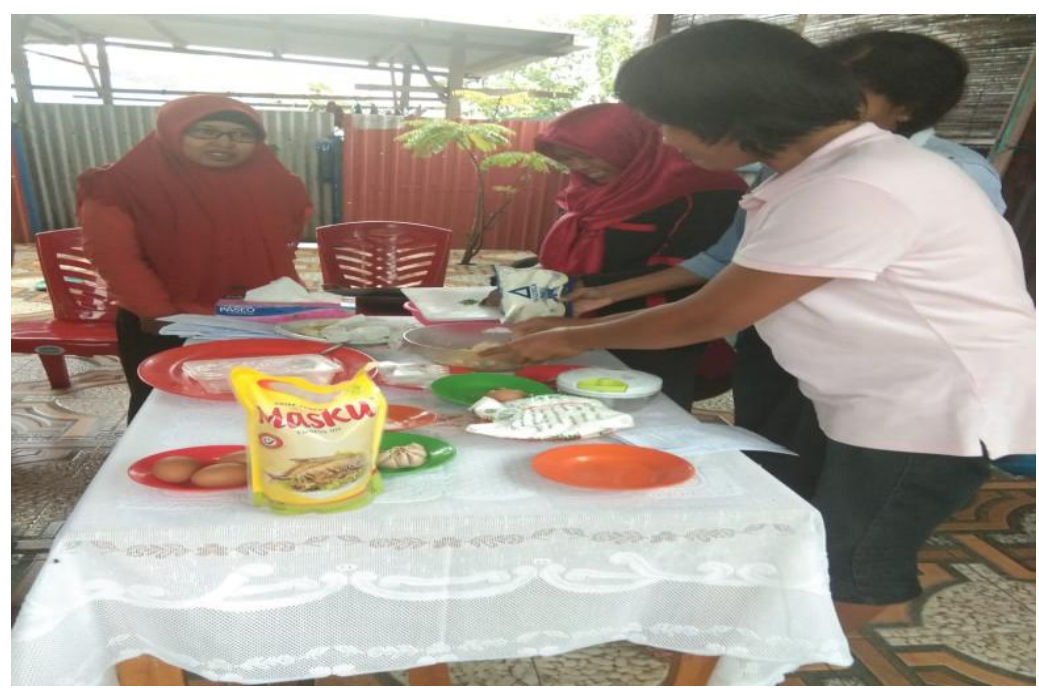

Gambar 5. Pelatihan Pembuatan Perkedel Ikan oleh Masyarakat

Perkedel tidak hanya dapat dibuat dengan berbahan kentang ataupun jagung, ikan sebagai salah satu bahan makanan sumber protein hewani yang cukup tinggi juga dapat disajikan dalam bentuk perkedel.

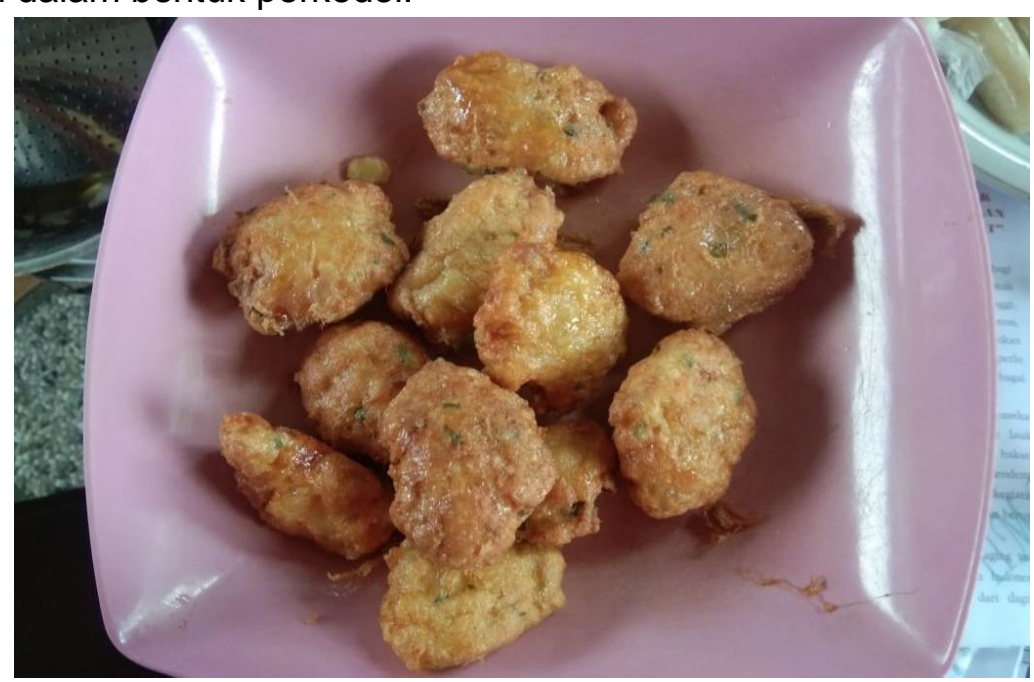

Gambar 6. Hasil Pelatihan Perkedel Ikan

Antusias masyarakat dalam hal ini ibu - ibu rumah tangga cukup antusias dalam mengikuti kegiatan, hal ini dapat dilihat dari peran serta mereka dalam mengikuti praktek - praktek yang dilakukan. 


\section{KESIMPULAN}

Kesimpulan yang diperoleh dari kegiatan pengabdian dengan judul "Pengolahan Produk Ikan Dan Pemberdayaan Kelompok Masyarakat" ini adalah potensi sumber daya alam berupa produksi ikan di Kabupaten Merauke cukup besar, namun keterampilan dari masyarakat dalam hal ini ibu - ibu rumeh tangga dalam mengolah menjadi beberapa produk masih sangat terbatas, hal ini secara tidak langsung mempengaruhi mayarakat terutama anak - anak dalam mengkonsumsi ikan. Melalui kegiatan pengabdian ini keterampilan yang dimiliki sebelumnya sangat terbatas kini semakin bertambah dalam mengelola aneka produk olahan ikan berupa bakso, sosis dan perkedel, sehingga diharapkan minat konsumsi ikan turut meningkat.

\section{DAFTAR PUSTAKA}

Gunawan Gladys, Edy Fadlyana. Kusnandi Rusmil. 2011. Hubungan Status Gizi dan Perkembangan Anak Usia 1 - 2 Tahun. Sari Pediatri, Vol. 13, No. 2, Agustus 2011.

Husain Rahim.,S. Suparmo, Eni Harmayani., Chusnul Hidayat. 2017. Kinetika Oksidasi Protein Ikan Kakap (Lutjanus sp) Selama Penyimpanan. AGRITECH, Vol. 37, No. 2, Mei 2017, Hal. 199-204. Universitas Gadjah Mada. Yogyakarta

Kabupaten Merauke Dalam Angka. 2018. Badan Pusat Statistik Kabupaten Merauke BPS-Statistic Of Merauke 